\title{
British Favoritism of Congress and the Speedy Transfer of Power
}

\author{
Mohammad Salim ${ }^{1}$, Saeed Ullah Jan ${ }^{2}$ \\ ${ }^{1}$ Department of Higher Education, Khyber Pakhtunkhwa, Peshawar, Pakistan \\ ${ }^{2}$ Department of Computer Science \& IT, University of Malakand, Chakdara, Pakistan \\ Email address: \\ saeedullah@uom.edu.pk (S. U. Jan), salimlec7@gmail.com (M. Salim)
}

\section{To cite this article:}

Mohammad Salim, Saeed Ullah Jan. British Favoritism of Congress and the Speedy Transfer of Power. Arabic Language, Literature \& Culture. Vol. 3, No. 2, 2018, pp. 9-15. doi: 10.11648/j.allc.20180302.11

Received: June 21, 2018; Accepted: July 6, 2018; Published: August 15, 2018

\begin{abstract}
World War II had shaken the bases capitalist yoke. The ever shining sun of British ascendency was on the verge of sinking. The two-edged sword of technological advancement and Machiavellian tactics of statecraft was no more paved her way in the eastern awakening society. British were facing failure in every sphere of politics in the subcontinent. The growing monstrous menace of the communist yoke at the western border and even inside insurgency of workers in India compel the British to transfer power to Hindu bourgeoisie. The capitalist Hindu bourgeoisie incarnated in a socialist garb was the lost ray of hope for the British. All these were possible in united India according to the then tank thank of British, while truncated moth-eaten Pakistan was not perceived as a strong bulwark against communist assault. Although the latter progress in the political history Pakistan has proven the opposite side of the portrayed arena. The purpose of this study is to explore the real cause of British favoritism of Congress and their tendency toward Hindu bourgeoisie. This paper attempts to answer those questions by objectively examining and analyzing the major events of the decade preceding the partition, unquestionably the most critical period to the understanding of the causes of partition.
\end{abstract}

Keywords: British, Congress, Muslim, Power, Division

\section{Introduction}

The age of renaissance in Europe reinvigorated the imperialistic designs of European nations. Control over the world wealth was the dream of all. The geographic isolation of England leads to isolation from war. In seven-year war started in 1756 and culminated in 1763. Having strong human and material resources the French failed to compete for the British in India, the queen of the ocean had controlled overall sea routes. Late in this race, the British become successful in subjugating the European on one hand and the Indian on the other. A fortune maker they fought for more than twenty years in southern India against European counterpart. Once succeeded in ousting their co-religionist from India they triumphed over all the rivals in India. In a century subdued every nook and corner of India. Following the policy of divide and rule on Indian soil, they implanted such a political system which was completely alien to the indigenous people. Body politics of Westminster type of democracy needed men of letters of British perception. Successful theirs efforts were in getting such men lacking
Indiana individualism through their educational system. By sheer dint of mind, treachery and with the help of these bottles-necks they maneuvered the political life of India. In the last decade of British rule 1937 to 1947 the sense of selfrule in Indian when reaching to the zenith of character during World War - II the British decided to transfer power to the Indian at last [1].

\subsection{Problem in Power Transfer}

The big problem of transfer of power was not the mechanism of transfer but to whom the power will be transferred. Who will be the faithful successor? Russiaphobia provided the British the soft choice of congress. It is clear from Attlee's this statement of 20 Feb 1947. His majesty's Govt will have to consider to whom the powers of central Govt in British India should be handed over, on due date, either as a whole to some form of central Govt British India or in some areas to the existing provincial Govt or in 
such other way as may seem most reasonable and in the best interest of Indian people. Once they found the choice of successor they lift no stone unturned to reward them whatever the way maybe [2].

\subsection{Cabinet Mission Plan}

In the legal framework of united India, the Muslim League had accepted the cabinet mission plan. For foresighted Jinnah, the grouping scheme was more attractive than truncated and moth-eaten Pakistan. Congress obduracy made the plan a fiasco. When the congress obstinate behavior was observed by the British they become lenient to them. Their interest can only be secured with co-operation of Congress in this region in the long run. Due to succumbed nature of British to Congress, this was the compulsion of Muslim league to reject the cabinet mission plan. The league leadership declared 16 August 1946 as a direct action day. When all the avenues were closed by the Congress then Jinnah during his stay in London categorically rejected the idea of united India and pleaded the demand for Pakistan in front international mass media. The rebound of direct action appeared in the unending series of communal riots in every nook and corner of India. Navakali, Garh Muktisher Calcutta and Bihar were the center of the bloodshed. Terrified from large sale bloodshed the British decided to include the congress and Muslim league in the interim government in order to control the imbroglio. Soon after the establishment of interim government, deadlock appeared on many issues between the two parties [2-3]. Both the parties were trying to subjugate each other. At last the British determined that moth-eaten truncated and impracticable Pakistan will be a better solution to this problem. In the long run, it will be easy for Congress to amalgamate this weak Pakistan in their tutelage. The viceroy Lord Wavell still wanted operationalization of the grouping scheme according to the real intention of the mission plan. The contradiction between Congress and Wavell leads to the dismissal of Lord Wavell at the behest of Congress. Incumbent upon his office on March 23, 1947 Lord Mount Batten decided that the proposed June 1948 is too late for the transfer of power. Congress was appropriate choice for the gift but the Muslim league was the obstacle between them. Lord mount batten ridiculed Jinnah and Muslim league and dubbed the demand of Pakistan as mad Pakistan. The Congress and its regent, at last, succumbed to transfer power to two dominions instead of one. The evidence is now clearer from the official document that the British were well aware of the bloodshed of Muslim and theirs forceful ousting from eastern Punjab was the real outcome of blindly followed division process and transfer of power [3].

\subsection{Main Theme of the Article}

The tumultuous lethal start of World War II and the Quit India movement when the British required the unflinching support of Indian army and treasury for wartime effort kept the British Govt between the devil and the deep sea. Gandhi a turbulent troublesome troublemaker was hated too much by Churchill. But in the span of fewer than four years, all was forgotten Nehru and Congress became the star of eyes of British [4].

Lord Atlee and his colleagues/ cabinet were so much zealous about Congress that they violated the basic spirit of centuries-old traditions and conventions of cabinet secrecy. All members observe secrecy and are responsible to defend it. As Lord Melbourne remark - all ministers tell the same story. This principle was undermined by Lord Pathik Lawrence. He was overtly in touch with Sudhir Gosh, who was not more than salesman of Tata group of industries. Lord Atlee and his team violated all the norms and values of British parliamentary system. There was no unity of thought and action. Being a prime minister of socialistic design and his team was so allergic to the ascendency of Russia that blindly tried to appease the Congress bourgeoisie whatever the cost of it may be. United India becomes a nightmare for them which they were observing through their kaleidoscope in dozing and jogging. Sudhir gosh was covertly and overtly conveying to Congress leadership which they fully exploited for pressurizing Lord Wavell [4].

When the cabinet mission plan became extremely controversial due to the daily objection and criticism of Congress the Attlee government took the issue to the supreme court of England in order to investigate the legal position of the plan. Lord Chancellor the highly respected incumbency in England, its interpretation of any act, plan is declared as final. Some time they interpret the act of parliament in such a way that it becomes clearly contradictory to what was the intention of lawmaker. After long deliberation, Lord Chancellor interpreted the plan exactly similar to that of Attlee's minister and Jinnah, but no heed was paid to the interpretation of this superb institution, so to appease and placate Congress [5].

\section{Review of Literature}

An act of parliament proposed a date for the transfer of power into Indian hands in June 1948, summarily advanced to August 1947 at the whim of the last viceroy, Lord Louis Mountbatten. This left a great many issues and interests unresolved at the end of colonial rule. In charge of negotiations, the viceroy exacerbated difficulties by focusing largely on Jinnah's Muslim League and the Indian National Congress. The two parties' representative status was established by Constituent Assembly elections in July 1946 but fell well short of a universal franchise [6].

Although Pakistan celebrated its independence on 14 August and India on 15 August 1947, the border between the two new states was not announced until 17 August. It was hurriedly drawn up by a British lawyer, Cyril Radcliffe, who had little knowledge of Indian conditions and with the use of out-of-date maps and census materials. Communities, families, and farms were cut in two, but by delaying the announcement the British managed to avoid responsibility for the worst fighting and the mass migration that had 
followed.

(1) The failure of the Cripps Mission caused profound disappointment in India. The Congress leaders realized that Britain was unwilling to concede to India real constitutional advance while the war lasted. Apart from that, popular discontent was on the rise against the soaring prices and wartime shortages.

(2) Cry of Pakistan for him. Mount batten called mad Pakistan [7].

(3) Mount Batten met Nehru in a hotel in 1946 become agreeable in first talk [25].

(4) Azad conceded that he was backed up by the governor of Punjab to oust Muslim league from forming a ministry [4].

(5) Lord mount batten and Sir Evan Janken agreed that a communal govt in Punjab will only make matters worse and section 93 must continue [17].

Prime Minister Churchill, Secretary of State for India Leo Amery, and Viceroy Linlithgow were all opposed to giving India more self-governance while the war lasted. Churchill wrote: 'The idea that we shall 'get more out of India' by putting the Congress in charge at this juncture seems illfounded. Amery thought that any settlement with the Congress Party would alienate the Muslims in India and it could hurt Britain's war efforts as most of the military recruits came from the Muslim race.100 Like Churchill, Linlithgow was an ardent imperialist who believed that the imperial interests would be best served by yielding nothing to India. Linlithgow thought that any real transfer of power would exacerbate the racial and religious divisions in the country. Moreover, Linlithgow hated the Congress politicians and had a very low opinion of them. Linlithgow wrote the following [26]:

"...there is no possibility of giving satisfaction to Congress or securing their real and wholehearted support. In my experience they are entirely ruthless politicians; will take all they can get; will do their utmost to maneuver us into a position in which we make sacrifices that are substantial and that will increase the prestige and power of Congress in the country [26].

Clement Attlee, who was the Lord Privy Seal in Churchill's Cabinet, opposed the policy of "do nothing" being advocated by the Secretary of State and the Viceroy. He proposed that a representative from London be sent to India to find a settlement with the Indian leaders to devolve more power into their hands. He thought that the hand-tomouth policy being followed by His Majesty's Government was not statesmanship; rather it was short-sighted and suicidal [26].

The Muslim League Working Committee met on 20 August, 1942, and passed a resolution condemning the Quit India movement. It described the movement as an attempt by the Congress to coerce the British Government to hand over power to a Hindu Oligarchy abandoning their obligations to the Muslims of India. 180 It went on to add [27].

"----The Working Committee are fully convinced that Pakistan is the only solution of India's constitutional problem and is in complete consonance with justice and fair play to the two great nations - Muslims and Hindus - inhabiting this vast subcontinent whereas if the Congress demand is accepted it would bring the 100 millions of Muslims under the yoke of the Hindu Raj...In these circumstances the Working Committee of the All-India Muslim League, call upon the Muslims to abstain from any participation in the movement initiated by the Congress and to continue to pursue their normal peaceful life [25].

(6) Pathak Lawrence in a letter to Cripps on $8^{\text {th }}$ November wrote that this feeling must not prevail that Sudhir Gosh is using us against viceroy [19].

The Gandhi-Jinnah meeting took place on 9 September at Jinnah's residence in Bombay and continued till 26 September, with brief intervals. Gandhi visited Jinnah's residence as many as fourteen times and several letters exchanged between the two leaders during that period. The fact that the talks continued for so long and in addition, the photographs of the two leaders smiling and cordially greeting each other, which the newspapers carried from day to day, created new hopes among the public that perhaps, at last, a settlement was around the corner. On 24 September Gandhi wrote a letter to Jinnah in which he said he could recommend to the Congress the acceptance of the claim of separation on the following basis [24]:

"......I proceed on the assumption that India is not be regarded as two or more nations, but as one family consisting of members of whom the Muslims living in the north-west zones i.e. Baluchistan, Sind, NWFP, and that part of the Punjab where they are in absolute majority and in parts of Bengal and Assam where they are in absolute majority...The areas should be demarcated by a commission, approved by the Congress and the League. The wishes of the inhabitants of the area demarcated should be ascertained through the votes of the adult population...if the vote is in favor of separation, it shall be agreed that these areas shall form a separate State as soon as possible after India is free from foreign domination...There shall be a treaty of separation, which should also provide for the efficient and satisfactory administration of Foreign Affairs, Defense, Internal Communications, customs, commerce, and the like [24].

As riots spread to other cities and the number of casualties escalated, the leaders of the Congress Party, who had initially opposed Partition, began to see it as the only way to rid themselves of the troublesome Jinnah and his Muslim League. In a speech in April, 1947, Nehru said, "I want that those who stand as an obstacle in our way should go their own way." Likewise, the British realized that they had lost any remaining vestiges of control and began to speed up their exit strategy. On the afternoon of February 20, 1947, the British Prime Minister, Clement Atlee, announced before Parliament that British rule would end on "a date not later than June, 1948." If Nehru and Jinnah could be reconciled by then, power would be transferred to "some form of central Government for British India." If not, they would hand over authority "in such other way as may seem most reasonable and in the best interests of the Indian people" [18].

(7) The Transfer of power scheme was designed [18]. 
(8) Mount batten declared the process of transfer of power should be speedy [22].

\section{Methodology}

Historical research, which needs interpreting past events to predict future ones, the researcher deemed it fit to concentrate on qualitative research, which involves analyzing non-numerical data. For writing this paper previously arranged data in various books journal internet was used by the researcher.

\section{Objectives}

The objectives of this research paper are as under:

(1) To figure out the answer to this question, why the British adopted the policy of immediate withdrawal from the subcontinent they carried out into action.

(2) To keep India united for theirs larger interest in South Asia in the future.

\section{Discussion}

This portion of the research paper shall be discussed under the following headings:

\subsection{Removal of Viceroy Lord Wavell}

The viceroy Lord Wavell was removed on the request of Congress. Wavell had become an object of controversy via his interpretation of cabinet mission plan, although he was strong supporter of united India. His explanation of cabinet mission plan similar to that of the league was a gigantic impediment for Congress to join the interim government. Gandhi declared that viceroy needs legal consultant, because he is lake of legal knowledge and he has lost his sense of judgment on communal riot [23].

\subsection{British Noninvolvement in Constitution Making}

Since the dawn British advent in the subcontinent all constitution plan were designed and implemented by British. Astonishing is that what made the British intellect fatigues that they declared their withdrawal from constitution-making which was their duty as a Dejure Sovereign. Mr. Atlee made it clear that India herself must choose, what will be her future constitution, what will be her position in the world. The British paid no heed to this constitution-making dilemma. The strength and constitution making capability of Congress were assessed by the British [20-21]. Any plan from the British if not satisfies the Congress would harm their longrange objective. They were only searching the ways and means to empower the Congress sooner in united India. By doing so they shall not be blamed for the dismemberment of Muslim league. It was clear that there was some opportunist politician in Muslim league leadership will soon favor congress united India slogan because they cannot remain outside the Govt. and the Congress can easily scatter the inner core of Muslim league by using different tactics. Atlee this statement prove this deduction; we are mindful of the right of minorities and minorities should be able to live free from fear. On the other hand we cannot allow a minority a veto on the advancement of majority [26].

\subsection{Muslim League Tax Imposition Decision on Middle Class Hindu Bourgeoisie Was Highly Disliked by Viceroy and Congress as Well}

The imposition of $25 \%$ tax on those businessmen whose income is greater than one lac of rupees shaken the Hindu bourgeoisie, which was the source of income of Congress. Congress declares this act as an attempt to widen the gulf between the socialist and rightist wing of Congress. Birla newspaper the Hindustan time's comment as quoted by Menon is such that; this budget has done damages to the British interest in India, which is capitalistic, Clive street is worried since the budget speech the stock exchange of Bombay Kolkata and Madras has been closed [18].

\subsection{League Congress Controversy at Apogee}

When the British government realized that the gulf between the two political parties is unbridgeable so they lift the idea of cabinet mission plan and made it clear bluntly that Muslim league could not be persuaded to come into the constitutional assembly then the part s of the country where they in majority [12-13]: ........ "In the result of this declaration a draft of transfer of power was made by Attlee administration. This original draft of transfer of power endorsed by Attlee administration was completely molded by lord mount batten on the request of Nehru. A new draft rearranged by VP Menon Batten constitutional adviser with the approval Nehru was implemented" [12-13].

\subsection{Polarization of Indian Masses}

The nominal Indian community, the social order established under British suzerainty and false slogan of Indian nationalism chanted by Indian national congress was weakened due to the preaching of different opposing ideologies by the two prevalent political parties. The unseen underground social volcanic lava was on the verge of bursting. The distrust between the two communities was at the zenith of intensity. Suspicion about each other rose to such an extent that the States in Bombay ousted all the Muslim servants from their jobs. Many of the recently jobless Pathans' were stabbed and massacred by disruptions Hindu hooligans at the instigation of influential Hindus. In retaliation, the Muslim community in Hazara district of the then North West Frontier Province (NWFP) started attacks on Sikh community. The Muslim community was in utter despair in Hindu majorities provinces. The Hindus in Bihar started lavishly vandalism against the Muslim. To overcome the situation seven battalions of the army were used. According to Francis taker core commander of eastern command, the chief minister of Bihar MR; Krishna Sinha seriously opposed the idea of using armed forces against the 
hooligans [17].

Sikh The reserve player was also grinding his axe to avoid the division of Punjab or push the depicted boundary line Trans Chenab. The governor of Punjab had aptly portrayed the situation, while writing a report to mount batten. Great harm will be experienced by the Sikh in Punjab. Division will be severe blow to the dominant position of Sikh in Punjab. Sikh political leadership is ready to fight tooth and nail for greater portion of Punjab. The reserve player was used by Congress leadership to make the of Punjab division inevitable. Having Khalistan in mind, the Sikh needed strong backup to push the Muslim westward. Early depicted and later burst lava of Muslim -Hindu communal riot disheartened the flinching hands of the loyal of the crown. To avoid this doomed day scenario at the last movement the British decision maker carved out the way for the speedy shameful plight of power in order to protect their honors and lives. In the nick of time, a political substitute in the form of Congress was also there to establish a neo-capitalist raj after withdrawal of British Raj [29-30].

\subsection{The Last Ray of Hope Was also Slipping into Irredeemable Spectrum}

The Indian armed forces which have served the British crown in the two great world wars and ruthlessly crushed every upsurge in India were reached in the tentacle of disintegration. The rebellion of the Indian naval forces in Feb 1946 had created dizziness in British mind. The civil unrest on sectarian basis and industrial workers obduracy deteriorated the situation to such an extent that at the end of 1946 the labor administration made an emergency scheme for the safe and peaceful withdrawal British citizen. The only ray of hope e.g. the Indian armed forces, which were still at the disposal of the British government seemed no more reliable after Punjab communal disturbances. The reason was the greater representation of Punjabis from the two opposite war race communities of Sikh and Muslims. The haste of the British did not make waste, so the lord Attlee government speeded up the process of transfer of power [10].

\subsection{Dreadful Sectarianism-Cum-Communism Nightmare for British}

The two prong attack of sectarianism and communism from northern and southern India won not allow a stress-free escape to British authorities from India. The courage of the communist proletarian class got momentum after the emergence of Russia as a superpower on the world scene. Hindu capitalist bourgeoisie was also allergic from the development in southern India. The congress political leadership perceived that they will become prey of isolationism after June 1948. Their slogan of the mass party in India will end in smoke. Although, the British government had already got surety of Stalin through their foreign secretary named Artist Bune in March 1946. At this critical juncture, the interest of Congress and British become parallel and they were playing on the same pitch. British benevolence of Congress and rapid endeavor for preparing a track for speedy transfer of power was the outcome of this defining movement [22].

\subsection{The Huge Work Load of Partition Was Tackled in Game Race Like Hurry}

In early May 1947 when the British government passed the initial plan of transfer of power and Lord Ismay was in London to put off Mount Batten suggestion to British government. So after a long and detailed discussion with Nehru mount batten sent a telegram to Lord Ismay to inculcate the British government that the base of the whole transaction is speeds e.g. the speedy transfer of power. So this process might be concluded in 1947 instead of June 1948. British Govt did not a stitch in time to save nine; every decision was made and implemented in hurry. It is evident from the $20 \mathrm{Feb} 1947$ proclamation of lord Atlee "his majesty government desire to hand over their responsibility to authorities established by a constitution approved by all parties in India in according with cabinet mission plan. But unfortunately there at present no clear prospect that such a constitution and such authorities will emerge. The present state of uncertainty is fraught with danger and cannot be indefinitely prolonged. His majesty government wishes to make it clear that it is their definite intention to take necessary steps to affect the transfer of power to the Indian hands by a date not later than June 1948" [14-15]. There was a time space of a complete one year from 3 June1937 to June 1948. But in spite of longtime schedule, the huge process of partition culminated in 72 days. Stanley Wolpert is wrong to say that mount batten completed the process in hurry to join his naval service in England. Actually he went to avoid the crux of matter. The detailed scrutiny of partition process means every legal claim of Muslim league would be honored which in turn will damage the Congress. The incumbency of governor general if become doubled was too much prestigious and honorable than the navel servicer of England. Astonishing character of the partition drama is that neither Atlee government nor British press admonish him for the hurry e.g. utilization of 72 days instead of 366 days. The division of assets, vast land and 400 million people seem mission impossible in such a short span [30].

\subsection{One Two or Super Governor General}

Security to the long-range objective in South Asia could only be insured by providing a joint foundation to the dominion of India and Pakistan. The sole panacea for this political imbroglio was joint governor-generalship. The British still wanted an active role in world politics. For this incumbency of joint governor mount batten used the good offices of Sir Walter Mongton and Nawab of Bhopal [11]. Batten turn down Jinnah idea of supper governor general and declared Jinnah decision as bum attack on his personality. $\mathrm{He}$ threatened Jinnah that Pakistan will lose her asset and future. British dominions were sovereign in each and every sphere. If Mont batten become joint governor general how he could 
control the two dominions is unthinkable [28].

\subsection{Neo-colonialism Instead of Imperialism}

Lust for power and supremacy over others is the foremost choice of each individual, nation, and state. British were seriously involved in this intricate race for the last three hundred years. World War II had derailed them from this role. They were discerning for the alternative. The ideology of neo-colonialism is impracticable without a sturdy state or sometime non-state actors. State actors with a strong position in a large a bulk population if available in a territory, while having no ancestral experience of imperialism beyond its frontiers is deemed a gigantic consecration [19]. Congress with all these attribute was present in front of imperialist British power. Muslim league the representative of Muslim community had along splendid past ancestral experience of reign over world was regarded as a deleterious choice for this role. Large party, numerous people, waste territory will best serve British interest. The later development proved the reality that the British companies worked for long time in India [16].

\section{Conclusion}

The security of British interest in South Asia in general and in the Indian Ocean, in particular, was the core issue of British foreign policy. The power vacuum created by British withdrawal from this region would be filled by such an actor who at least could provide a guaranty to their interest. So the role was handed over to the Congress on land and to the USA in water. The congress was also favored that it will provide an impediment to Russian communism and expansionism.

\section{References}

[1] Ahmad, J. (1960). Speeches and writings of Mr. Jinnah, op. cit, $2,220$.

[2] Ali, C. M. (1967). The emergence of Pakistan (p. 357). New York: Columbia University Press.

[3] Ali, R. U. (2009). Planning for the Partition of India 1947: A Scuttled Affair. Pakistan Journal of History \& Culture, 30(1).

[4] Azad, M. A. K. (1949). India Wins Freedom (1949).

[5] Campbell-Johnson, A. (1972). Mission with Mountbatten. Robert Hale.

[6] Chaudhri, M. A. (1967). The emergence of Pakistan. Research Society of Pakistan, University of the Punjab, 354.

[7] Choudhury, G. W. (1969). Constitutional development in Pakistan. Publications Centre, University of British Columbia.
[8] Ghosh, S. (1967). Gandhi's emissary. Cresset Publication.

[9] Guha, R. (1997). Dominance without hegemony: History and power in colonial India. Harvard University Press.

[10] Hoodbhoy, P., \& Nayyar, A. H. (1985). Rewriting the history of Pakistan. Islam, politics and the state, 164-177.

[11] Hunter, W. W. (1899). A History of British India: To the overthrow of the English in the Spice Archipelago [1623 (Vol. 1). Longmans, Green, and Company.

[12] Isaacs, S. (1967). Gandhi's Emissary.

[13] Johnson, A. C. (1951). Mission with Mountbatten. London, R. Hale.

[14] Saeed Ullah Jan, Education in the Age of Technology: Contrasting Fortunes, Science Journal of Education. Vol. 6, No. 2, 2018, pp. 55-70. doi: 10. 11648/j. sjedu. 20180602. 13

[15] Kalam, A. M. A. (1988). India wins freedom.

[16] Khan, A. W. (1961). India Wins Freedom: The Other Side. Pakistan Educational Publication.

[17] Maunawar, A. K. (1980). Dimention of Pakistan Moment, 1(1), Service Book Club, Lahore, Pakistan.

[18] Menon, V. P. (1957). Transfer of power in India.

[19] Meyer, C. (1947). Peace or anarchy. Little, Brown.

[20] Moon, P. (1962). Divide and quit. Univ of California Press.

[21] Moore, R. J. (1983). Jinnah and the Pakistan demand. Modern Asian Studies, 17(4), 529-561.

[22] Nicholas, M. E, (1981) Transfer of Power, 10(1), London Press.

[23] Pakistan as a peasant utopia: the communalization of class politics in East Bengal, 1920-1947 by Taj ul-Islam Hashmi.

[24] Quershi, I. H. (1974), Struggle for Pakistan, Karachi Press.

[25] Rizvi, G. (1978). Before and after the transfer of power: Two review articles: II-Lord Linlithgow and the reviewers. South Asia: Journal of South Asian Studies, 1(1), 114-119.

[26] Sayeed, K. B. (1960). Pakistan: The Formative Phase. Pakistan Publishing House.

[27] Singh, K. (2005). Train to Pakistan. Orient Blackswan.

[28] Spear, P., Thapar, R., \& Spear, T. G. P. (1990). A history of India (Vol. 2). Viking Pr.

[29] Stephens, I. M. (1964). Pakistan: old country new nation. Penguin Books.

[30] Tuker, F. I. S. (1950). While memory serves. 


\section{Biography}

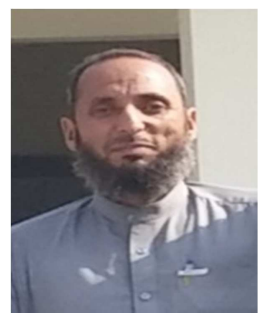

Mohammad Salim received MA Political Science from University of Peshawar Pakistan and MA Pakistan Studies from Islamia University of Bahawalpur, Pakistan. He is working as Assistant Professor of Pakistan Studies at Higher Education, Achieves \& Libraries Department Govt of Khyber Pakhtunkhwa and Controller of Examinations for 09 BS Disciplines at Govt College Wari Dir Upper. His research interest includes Indo-Pak, American, British and China History. Besides this, he is also command over Islamic/Religious affairs.

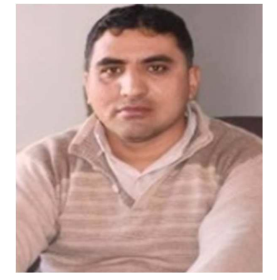

Saeed Ullah Jan received MPhil degree in Network Security from the University of Malakand in 2016. He is working as Lecturer in Computer Science at Higher Education, Achieves \& Libraries Department Govt of Khyber Pakhtunkhwa - Pakistan. His research interests include Information Security, VoIP, SIP Authentication, Cloud Computing, and Parallel Privacy-Preserving Authentication. $\mathrm{He}$ is also working as BS - Coordinator at Govt College Wari (Dir Upper) for 09 BS Disciplines in the far-flung remote area of the province where most of the Youngers have no access to Universities/institutions for Higher Education. Currently, he is Ph.D. scholar in the Department of Computer Science \& IT University of Malakand. 